\title{
An Update On 401(K) Plans In The United States
}

John J. Lucas, Purdue University Calumet

\begin{abstract}
Today, 401( $k$ ) plans have become one of the most popular retirement savings programs offered by corporate America. With their enormous popularity, 401 $(k)$ plans have experienced spectacular growth and expansion since their creation under the Revenue Act of 1978. It is estimated that there are 423,000 401 $(k)$ plans in the United States with an estimated 1.8 trillion dollars in assets. (EBRI Facts, 2005) This paper traces the creation and establishment of 401( $k$ ) plans in the United States. A discussion pertaining to the recently passed Pension Protection Act of 2006 and its major changes regarding 401( $k$ ) plans will also be provided in order to assist business leaders in continuing to offer this very popular retirement program.
\end{abstract}

\section{BACKGROUND}

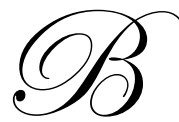

asically, a 401(k) plan is a defined contribution plan that allows plan participants to defer a portion of their salary into a qualified retirement plan. These retirement plans, also known as cash or deferred arrangements (CODAs), were named after the section of the Internal Revenue Code that created them. 401(k) plans apply to private-sector employers with similar retirement plans authorized under the tax code for public-sector employees (457 plans) and non profit-sector employees (403(b) plans) (EBRI Facts, 2005).

Under a 401(k) plan, a plan participant may defer a portion of his or her salary into an established individual account as a pretax or post tax reduction (Lucas, 2007). As outlined under the Economic Growth and Tax Relief Reconciliation Act of 2001, the maximum annual deferral by a plan participant was restricted to an employee contribution limit of $\$ 15,000$ in 2006, with amounts indexed for inflation thereafter (EBRI Facts, 2005). The employee contributions were invested in an array of investment vehicles, such as stocks, bonds, mutual funds, or fixed funds (Lucas, 2007). Many employers also provide matching contributions to the employee accounts made in whole or in part, up to some percentage of the employee's base salary (GAO, 2002). Typically, companies provide a limit of three percent of an employee's salary (Clark, 2005). Thus, a typical 401(k) plan consisted of three major accounts: a pretax account, a post tax account, and an employer matching contribution account.

Additionally, there were distribution restrictions for a 401(k) plan. The account balances were distributed to a plan participant only on retirement, age 59.5, hardship, death, disability, or separation from company service (Beam and McFadden, 2005). If an early distribution occurred, the plan participant was subject to a ten percent withdrawal penalty, as prescribed under Code Section 72(t).

A plan participant was permitted to borrow from vested accounts of the qualified plan under Code Section 72(p), if the plan permitted such loans. According to the Profit Sharing/401(k) Council of America, eighty five percent of employers permit employees to take a 401(k) loan (Bigda, 2007). A loan granted to the employee was one-half of the present value of the vested accounts. For example, if the employee has $\$ 30,000$ in his/her account, a loan of $\$ 15,000$ was permissible. The loan must be repayable by the employee within five years. A qualified 401(k) plan permitted one loan a year, with a maximum of five outstanding loans. If the employee left the company before repayment of the loan, it was considered an early withdrawal and subject to a ten percent penalty on the remaining balance. 


\section{HISTORY OF 401(K) PLANS}

Today, 401(k) plans have become one of the fastest growing retirement programs offered by corporate America. According to Employee Benefit Research Institute (EBRI), there were an estimated 423,000 401(k) plans, with an estimated total assets of 1.8 trillion dollars (EBRI Facts, 2005). This raises the question on how 401(k) plans were developed and gained such enormous popularity as a retirement plan in corporate America.

Prior to the passage of the Revenue Act of 1978, there were some deferred compensation arrangements being offered by American companies; however, there existed continuous disagreements between the IRS and employers regarding the extent of restriction on such cash or deferred arrangements (EBRI Facts, 2005). The passage of ERISA of 1974 froze an IRS proposal that would have greatly restrain the tax-deferred status of these deferred compensation arrangements (EBRI Fact, 2005). As a result, the IRS withdrew its proposed regulations and ERISA mandated a research study pertaining to salary reduction plans. This requested study by ERISA provided the impetus for legislation to create 401(k) plans (EBRI Facts, 2005).

The Revenue Act of 1978 contained the Internal Revenue Code (IRC) Section 401(k) that allowed employees to defer a portion of their salary without taxation. This law went into effect on January 1, 1980 with regulations issued in November of 1981 (EBRI Facts, 2005). With the passage of the Revenue Act of 1978, several major Fortune 500 companies, such as Johnson and Johnson, PepsiCo, J.C. Penney, Honeywell, and Hughes Aircraft, implemented 401(k) plans as part of their retirement benefits.

In 1981, the IRS sanctioned the use of employee salary reduction as a legitimate source of retirement plan contributions for workers participating in 401(k) plans (EBRI Facts, 2005). The Tax Reform Act of 1984 required "nondiscrimination" testing for 401(k) plans to assure that the contributions of these plans did not discriminate in favor of highly compensated employees. Two years later, the Tax Reform Act of 1986, placed very stringent guidelines for meeting nondiscrimination rules and also reduced the maximum annual 401(k) before-tax salary deferrals by employees (EBRI Facts, 2005). By 1990, the number of 401(k) plans offered by corporate America had grown to 97,614 with total assets of $\$ 384.85$ billion (EBRI Facts, 2005).

In 1992, the Unemployment Compensation Amendments also provided a provision for a twenty percent mandatory tax, if a lump-sum distribution was not rolled over into another qualified retirement plan, annuity, or an individual retirement account (IRA). For example, if an employee left a company and had an account balance of $\$ 40,000$ in a $401(\mathrm{k})$ plan, the individual must rolled over the $\$ 40,000$ into another $401(\mathrm{k})$ plan or IRA within sixty days to avoid the twenty percent penalty of $\$ 8,000$. By 1996 , the number of $401(\mathrm{k})$ plans had expanded to 230,808 with total assets of 1.06 trillion (EBRI Facts, 2005).

The passage of the Economic Growth and Tax Relief Reconciliation Act (EGTRRA) of 2001 included several modifications to the 401(k) plan offered in corporate America. One major modification within the context of the Act was an increase in annual deferral limit for 401(k) plans, 403(b) plans, and 457 plans. Commencing in 2002 , the annual deferral limit was $\$ 11,000$ in $2002, \$ 12,000$ in $2003, \$ 13,000$ in $2004, \$ 14,000$ in $2005, \$ 15,000$ in 2006, and indexed amounts to inflation thereafter. Still another modification was a "catch-up" provision that permitted plan participants, aged 50 or older, to increase their contributions up to $\$ 1,000$ in 2002, $\$ 2,000$ in 2003 , $\$ 3,000$ in $2004, \$ 4,000$ in 2005 , and $\$ 5,000$ in 2006, and also indexed thereafter (EBRI Facts, 2005). Starting in 2006, the Act also allowed plan participants to defer a portion of their salary into an after-tax Roth contribution.

In 2002, Congress passed the Corporate and Auditing Accountability Responsibility and Transparency Act also referred to as the Sarbanes-Oxley Act. The passage of this federal law was a direct response by Congress to the public outcry pertaining to the Enron and WorldCom corporate scandals. The law contained two primary provisions that impacted 401(k) plans. First, "insider trades" by senior leadership is prohibited during trading blackout periods. Second, a thirty day advance notification to plan participants and beneficiaries must be given by plan administrators prior to the imposition of a trading black out. If notification is not given, plan administrators are subject to civil penalties (EBRI Facts, 2005). By the end of 2003, there was an estimated 438,000 401(k) plans in corporate America with total assets of $\$ 1.9$ trillion dollars. 
Today, 401(k) plans continue to experience continual growth and popularity as a result of employers freezing their traditional defined benefit plans in favor of 401(k) plans. Major corporations such as Verizon Communications, IBM, Alcoa, and Sears Holdings have frozen their defined benefit plans and enhanced their defined contributions plans as a cost saving measure (Lucas, 2007). For example, Verizon Communications froze their pension plan in June 2006 and increase its contribution to the workers' accounts. It was estimated that Verizon Communications could realize a savings as much as three billion dollars over the next ten years (Searcey and Drucker, 2005). Likewise, IBM also announced that it would freeze its defined benefit plan beginning in 2008, and enhanced its contribution to the workers' $401(\mathrm{k})$ plan for its 117,000 affected employees. Keep in mind that employers also highly favor defined contribution plans because they are not responsible for the investment risk of these plans as this responsibility is shifted to the employee, unlike a traditional defined benefit plan.

\section{PENSION PROTECTION ACT 2006}

On July 28, 2006, the House of Representatives passed the Pension Protection Act, H.R. 4, by a vote of 279-131, and the bill was successfully passed by the Senate by a vote of 93-5. On August 17, 2006, President George W. Bush signed into law P.L. 109-280, also known as the Pension Protection Act of 2006. The Act has been referred to as the "most comprehensive reform of the nation's pension laws since the enactment of the Employee Retirement Income Security Act (ERISA) of 1974."

The 907-page bill contained fourteen major Titles ranging from Title 1-"Reform of Funding Rules for Single-Employer Defined Benefit Pension Plans" to Title XIV_"Tariffs Provisions." There were two primary Titles of the Act that had implications for defined contribution plans offered by employers. Title IX entitled "Increase in Pension Plan Diversification and Participation and Other Pension Provisions" specifically provided guidelines for defined contribution plans. Title VI referred to as "Investment Advice, Prohibited Transactions, and Fiduciary Rules" also had direct implications for defined contribution plans.

Under Title IX Section 901, the Internal Revenue Code of 1986 Section 401 was amended by adding a new paragraph (35) entitled "Diversification Requirements for Certain Defined Contributions Plans." Basically, this new paragraph assured employees the freedom to invest their assets of a defined contribution plan offered by an employer. In essence, the contributions made by the employee may be diversified at all times, while the employer contributions may be diversified after the employee completes three years of service at the company (Binney, 2006). Additionally, the defined contribution plan must offer at least three investment options other than employer securities to which an employee may direct his/her proceeds from the plan (U.S. Public Law109-280, 2006). Clearly, this section of the Act was a direct response by lawmakers to the Enron collapse where employees were limited to investing Enron stock in their $401(\mathrm{k})$ plans. It was estimated that $\$ 2$ billion was lost in the retirement plans at Enron (Associated Press, 2007).

Section 902 of Title IX afforded employers the opportunity to increase employee participation in their defined contribution plans through automatic enrollment. Under this section of the law, the 401(k) section of the Internal Revenue Code of 1986 was, once again, modified by adding a paragraph (13) entitled "Alternative Method for Automatic Contribution Arrangements to Meet Nondiscrimination Requirements" (U.S Public Law 109-280, 2006). Under this provision of the law, automatic enrollment was permissible by an employer only if the plan participants were informed that they may opt out of the 401(k) plan, and that they may also change their contribution levels (Binney, 2006).

This section of the Pension Protection Act also established a "safe harbor" from nondiscrimination testing for $401(\mathrm{k})$ plans, if certain requirements are meet. For the employer to qualify for the automatic "safe harbor," the contribution rate for automatic enrollees must be at least 3\% during the first year; 4\% during the second year, 5\% during the third year, and 6\% thereafter, up to cap participation of $10 \%$ of compensation (Purcell, 2006). The plan participant, who is automatically enrolled in the $401(\mathrm{k})$ plan, has ninety days to withdraw from the plan. Any employer contributions and earnings on those contributions were not subject to the ten percent extra tax penalty that applied to distributions received before the age of 59.5. This tax rule also applied to 403(b) plans as well as 457(b) plans that also have automatic enrollment (Purcell, 2006). Therefore, this section of the law clarified the standards 
for meeting nondiscrimination rules, set certain levels for automatic contributions, and also preempted any state laws that restricted this opportunity (Leonard, 2006).

Another major title of the Pension Protection Act of 2006 that had implications for 401(k) plans was Title VI-Subtitle A- "Investment Advice." Title VI Subtitled A amended section 408(b) "Exemption From Prohibited Transactions" of ERISA of 1974. Under a new paragraph (14), employers were permitted to provide investment advice pertaining to $401(\mathrm{k})$ plans. In other words, certain designated financial advisers were permitted to receive compensation in exchange for providing investment advice without violating the "prohibited transactions" provision prescribed under ERISA (Purcell, 2006).

Under Title VI, the term "fiduciary adviser" was described as a person: (1) registered as an investment adviser under the Investment Act of 1940; (2) bank or similar financial institutions; (3) insurance company qualified to do business under the law of a State; (4) a broker or dealer under the Securities Exchange Act of 1934 (PL 109280, 2006). The qualified fiduciary adviser might be associated with the investment instruments offered in the 401(k) plan, provided that the individual discloses service fees, limitations on scope of the advice, and any services provided with respect to the advice (Purcell, 2006). Additionally, advisers were required to base their financial recommendations on a computer model certified and audited by an independent third party (Binney, 2006). The Department of Labor, in consultation with the Treasury Department, was given the authority to determine if a computer model existed to tailor the employees' needs, based upon their financial and family circumstances. If they were unable to certify that such a model existed, the fiduciary adviser might continue to provide such investment advice, as long as he/she would certify in writing that their company has adopted written policies and procedures ensuring that the investment advice was appropriate (Purcell, 2006).

\section{CONCLUSION}

This paper traced the historical beginnings of the 401(k) plan in corporate America from its creation under the IRC Code section 401(k) of the Revenue Act of 1978 to its future with the passage of the Pension Protection Act of 2006. The 401(k) plan has become an enormously popular retirement plan in corporate America and continues to experience significant growth in terms of the number of participants as well as dollars in assets. According to the Investment Company Institute, in 1978, there were 30 million active participants in defined benefit plans, 19 million active participants in non-401(k) defined contributions plans, and almost no one in 401(k) plans. However, this trend has reversed after twenty five years, as there were estimated 47 million $401(\mathrm{k})$ participants, 21 million participants in defined benefit plans, and 8 million in other defined contribution plans (Mincer, 2006). Today, it is estimated that there are $423,000401(\mathrm{k})$ plans with an estimated 1.8 trillion dollars.

The outlook for 401(k) plans looks very favorable because of two primary factors. One factor is the growing trend that major employers continue to freeze their traditional defined benefit plans in favor of 401(k) plans. The impetus to freeze defined benefit plans is simply to reduce the financial costs as well as the liabilities of maintaining them. As a cost saving measure, therefore, employers have been very willing to switch from a defined benefit plan to a defined contribution plan (Lucas, 2007). As a consequence, in the past few years, defined benefit plans have declined dramatically, while 401(k) plans have continued to experience spectacular growth.

The second major factor for the favorable outlook for 401(k) plans is the passage of the Pension Protection Act of 2006. This federal law provides employers the opportunity to increase employee participation in their defined contribution plans through automatic enrollment. According to a recent Fidelity Investment survey of 400 plan sponsors, the number of defined contribution plans featuring automatic enrollment in 2006 rose ninety five percent compared to the previous year. Additionally, forty four percent of the plan sponsors, who currently do not offer auto enrollment programs, plan to implement such a program in 2007 (Miller, 2007). Clearly, the automatic provision makes it easier for an employer to enroll their employees in $401(\mathrm{k})$ plans. However, the question remains whether automatic enrollment will be advantageous for plan participants.

The Pension Protection Act also permitted employers the opportunity to provide investment advice to employees pertaining to their $401(\mathrm{k})$ plans. This was the first time that employers can provide a mutual fund 
company, insurance company, or investment broker to provide investment advice to their employees since it was expressly forbidden under ERISA (Lauricella, 2006). The intent is for plan participants to utilize investment advice in order to make appropriate investment selections in their 401(k) plans. It remains to be seen if the investment advice given by the fiduciary advisers is truly in the best interest of the plan participants. Recently, the Supreme Court announced that it would review an Appeal Court's ruling that a 401(k) plan participant had no right to sue under ERISA for an alleged mishandling of investments in a plan account (Smith, 2007).

When the 401(k) plan was created under the Revenue Act of 1978, it was a relatively unknown retirement option for corporate America. At that time, 401(k) plans were designed to only supplement the retirement programs offered by employers. However, 401(k) plans have become increasingly the primary retirement choice offered by employers. With the passage of the Pension Protection Act, 401(k) plans were given a new "makeover" with provisions for automatic enrollment and investment advice. The Pension bill has been viewed as the "funeral service for defined plans in corporate America" (Lucas, 2007). If that is true, 401(k) plans, a relatively unknown retirement option in 1978, will continue to dominant the retirement plan landscape in corporate America.

\section{REFERENCES}

1. $\quad$ Associated Press, Prison Term in Enron Case. Wall Street Journal, 19 July 2007, sec C-2.

2. $\quad$ Beam, Burton T. Jr., and John McFadden (2005). Employee Benefits, $7^{\text {th }}$ ed. Dearborn Real Estate Education.

3. Bigda Carolyn, 401(k) loan can be easy, costly. Chicago Tribune, 18 March 2007, sec 5-6.

4. Binney, Erin. Pension Legislation Affects More Than Just Defined Benefit Plans. www.shm.org. Accessed September 19, 2006.

5. $\quad$ Clark, Kim. Pension Tension. U.S. News and World Report, 24 January, 2005.

6. Employee Benefit Research Institute (February, 2005). History of 401(k) Plans: An Update. Washington, D.C. www.ebri.org.

7. Lauricella, Tom. The 401(k) of the Future. Wall Street Journal, 5-6 August 2006, sec. B-1.

8. Leonard, Bill. Congress Passes Landmark Reform Bill, www.shrm.org. Accessed August 11, 2006.

9. Lucas, John J. What is the Future for Defined Benefit Plans in the United States? Journal of Business and Behavioral Sciences, Vol. 15, No., Spring 2007.

10. Miller, Stephen. 401(k) Automatic Enrollment Nearly Doubled in 2006, www.shrm.org. Accessed March 6, 2007.

11. Mincer, Jillian. As the 401(k) Turns 25, Has It Improved With Age? Wall Street Journal, 14 November 2006, sec. D-2.

12. Purcell, Patrick. H.R. 4: The Pension Protection Act. CRS Report for Congress, 27 September 2006.

13. Purcell, Patrick. Summary of the Pension Act of 2006. CRS Report for Congress, 23 October 2006.

14. Searcey, Dionne and Jesse Drucker, Verizon to Cut Manger Pensions. Wall Street Journal, 6 December 2005, sec A-8.

15. Smith, Allen. Supreme Court Will Review Whether 401(k) Plan Has Remedy. www.shrm.org. Accessed July 7, 2006.

16. U.S. General Accounting Office. 2002. Answers to Key Questions About Private Pension Plans. Washington, D.C.

17. U.S. Public Law 109-280. $109^{\text {th }}$ Congress. 17 August 2006. Pension Protection Act of 2006. 
NOTES 